\title{
THE IMPACT OF THE COVID-19 PANDEMIC AND THE DROUGHT ON THE PRICES OF THE MAIN AGRICULTURAL PRODUCTS OF ANIMAL ORIGIN IN ROMANIA
}

\author{
Daniela Nicoleta BADAN (VOICILA)'1, PhD Student, \\ Research Institute for Agriculture Economy and Rural Development (ICEADR), \\ Bucharest, Romania \\ Ionut Laurentiu PETRE', PhD Student, \\ Research Institute for Agriculture Economy and Rural Development (ICEADR), \\ Bucharest, Romania
}

DOI: https://doi.org/10.36004/nier.es.2020.2-09

JEL Classification: IO, I12, Q1, Q11, Q13, Q15

UDC: 338.5:637(498)

\section{ABSTRACT}

Globally, the pandemic installed by the coronavirus has led to a change in the way business is conducted. In the context of the economic crisis knocking on the door, the states of the world are trying to take the most severe measures to mitigate the effects of this epidemic. One sector of the economy that needs to be protected is agriculture, because it provides the much-needed food for everyone. The role of farmers is very important in this equation, as they provide the necessary food stabilizing stocks of food that can be depleted faster. In this paper we want to determine the possible impact that the drought and the overlap of the COVID pandemic on it may have on the prices of agricultural products of animal origin in Romania. In this context, the level of prices in the first half of the previous year was compared with the level of prices in the first half of the current year, in order to be able to determine, from a statistical point of view, whether there are significant differences. It was found that for five of the six products analyzed, the prices in the first half of 2020 were higher than in the first half of 2019. Following this analysis, the correlation coefficients between the price level and the precipitation level were determined, and subsequently between the price level and the market demand, the latter influenced by the pandemic. It was found that both phenomena indirectly influenced the prices of agricultural products of animal origin.

Keywords: animal products, prices, COVID pandemic, drought, Romania.

La nivel global, pandemia instalată de coronavirus a condus la o schimbare a modului în care se desfășoară activitatea. În contextul crizei economice, care bate la ușă, statele lumii încearcă să ia cele mai severe măsuri pentru a atenua efectele acestei epidemii. Un sector al economiei care trebuie protejat este agricultura, deoarece oferă hrana atât de necesară pentru toată lumea. Rolul fermierilor este foarte important în această ecuație, deoarece aceștia asigură stocurile necesare de stabilizare a alimentelor care pot fi epuizate mai repede. În această lucrare dorim să stabilim impactul posibil pe care îl poate avea seceta și suprapunerea pandemiei COVID asupra prețrilor produselor agricole de origine animală din România. În acest context, nivelul prețurilor din prima jumătate a anului precedent a fost comparat cu nivelul prețurilor din prima jumătate a anului curent, pentru a putea determina, din punct de vedere statistic, dacă există diferențe semnificative. $S$-a constatat că pentru cinci din cele șase produse analizate, prețurile din prima jumătate a anului 2020 au fost mai mari decât în prima jumătate a anului 2019. În urma acestei analize, s-au determinat coeficienții de corelație dintre nivelul prețului și nivelul de precipitații, iar ulterior între nivelul prețurilor și cererea pieței, aceasta din urmă influențată de pandemie. S-a constatat că ambele fenomene au influențat indirect prețurile produselor agricole de origine animală.

Cuvinte-cheie: produse de origine animală, prețuri, pandemie COVID, secetă, România.

${ }^{1}$ ID ORCID 0000-0003-3648-7618\e-mail: badan.daniela@iceadr.ro

2 ID ORCID 0000-0002-2360-6844 \e-mail: petre.ionut@iceadr.ro

December No. 2/2020 
В глобальном масштабе пандемия, вызванная коронавирусом, привела к изменению способов ведения бизнеса. В условиях стучащегося в дверь экономического кризиса государства мира пытаются принять самые жесткие меры для смягчения последствий этой эпидемии. Одним из секторов экономики, который необходимо защитить, является сельское хозяйство, потому что оно обеспечивает столь необходимую пищу для всех. В этом уравнении очень важна роль фермеров, поскольку они обеспечивают необходимые продовольственные стабилизирующие запасы продовольствия, которые могут быть истощены быстрее. В этой статье мы хотим определить возможное влияние, которое засуха и наложение пандемии COVID на нее может оказать на цены на сельскохозяйственную продукцию животного происхождения в Румынии. В этом контексте уровень цен в первом полугодии предыдущего года сравнивался с уровнем цен в первом полугодии текущего года, чтобы можно было определить со статистической точки зрения, есть ли значительные различия. Было установлено, что по пяти из шести проанализированных продуктов цены 8 первой половине 2020 года были выше, чем в первой половине 2019 года. После этого анализа были определены коэффициенты корреляции между уровнем цен и уровнем осадков, а затем между уровнем цен и рыночным спросом, на последний повлияла пандемия. Выяснилось, что оба явления косвенно влияют на цены на сельскохозяйственную продукцию животного происхождения.

Ключевые слова: продукты животного происхождения, цены, пандемия COVID, засуха, Румыния.

\section{INTRODUCTION}

An extreme drought phenomenon was registered in Romania, at the beginning of the 20192020 agricultural year, specifically at the beginning of September 2019 which greatly affected the main vegetable crops. The drought continued in the first quarter of 2020 , so, in addition to autumn crops, spring crops were also affected. An indisputable proof in this respect is the fact that, at the proposal of the Ministry of Agriculture and Rural Development, a law was drafted (emergency decree no. 148/2020) regulating compensations for the affected areas (Official Gazette, 2020).

Over this difficult period for agriculture from a climatic point of view, the onset of the COVID19 epidemic in Romania, which directly influenced the agri-food sector, also proved to be an overlapping cause. Butu et al. (2020), who studied the impact of the COVID-19 crisis on the buying behavior of fresh vegetable consumers found that the pandemic induced significant changes in the buying behavior of shoppers. In addition to these demand-related issues, it is considered that this crisis has also led to a reduction in the supply of products, given the limitations on trade.

Zhang et al. (2020), who wanted to assess the potential economic cost of the COVID pandemic in China for the agri-food system, found the following in his paper: the economic loss of the agrifood system is equivalent to $7 \%$, about $27 \%$ of the total workforce having lost their jobs. At the same time, the results show that the continuous reduction of economic dependence on exports and the stimulation of domestic demand are key areas that require political support.

We consider that these two phenomena have to some extent influenced the evolution of agricultural product prices, so another research question is to what extent have the pandemic and drought affected the price of agricultural products of animal origin.

To this research question, there is a hypothesis based on other studies (Zhang et al. 2020, Anh and Gan, 2020, Fan and Zhang, 2020), namely that these phenomena indirectly influence the price level of agricultural products of animal origin. This hypothesis can also be supported by the findings of Cao et al. (2020), which conducted an analysis of the impact of the pandemic on agricultural imports and exports from China, and the authors note that exports were negatively affected, both in the short and long term.

\section{MATERIAL AND METHOD}

In this paper we want to analyze the price dynamics for the main agricultural products of animal origin in Romania, and then determine the influence that the COVID-19 pandemic may have, but also the severe drought since the beginning of the agricultural year. In this sense, we will analyze statistical data taken from the National Institute of Statistics (INS) both quantitatively and 
qualitatively with reference to the price of these products, making a comparative analysis of the first half of 2020 with the first half of 2019, and subsequently aspects related to drought (precipitation level) will be analyzed with the help of meteorological data provided by different weather stations, whiel at the end the consumption of these products will be analyzed as a phenomenon of pandemic.

These data will be analyzed statistically using the $t$ test, hypothesis testing and the Pearson correlation coefficient. The research will analyze a series of agricultural products of animal origin that are very important in human nutrition, namely: the main varieties of meat (cattle, sheep, poultry and pigs), cow's milk and eggs.

\section{RESULTS AND DISCUSSIONS}

In order to be able to determine the influence of the COVID-19 pandemic and the drought on prices, a quantitative analysis of the evolution of prices for the main agricultural products of animal origin in Romania must be carried out beforehand. This analysis will be performed comparatively, respectively it will put the price of products from the first half of 2019 against the price of products from the first half of 2020. Subsequently, the hypothesis will be tested according to which the price differs in 2020 compared to 2019, registering an increase, this analysis will be performed with the $\mathrm{t}$ test, from the Data Analysis package of MS Excel.

\section{Beef meat}

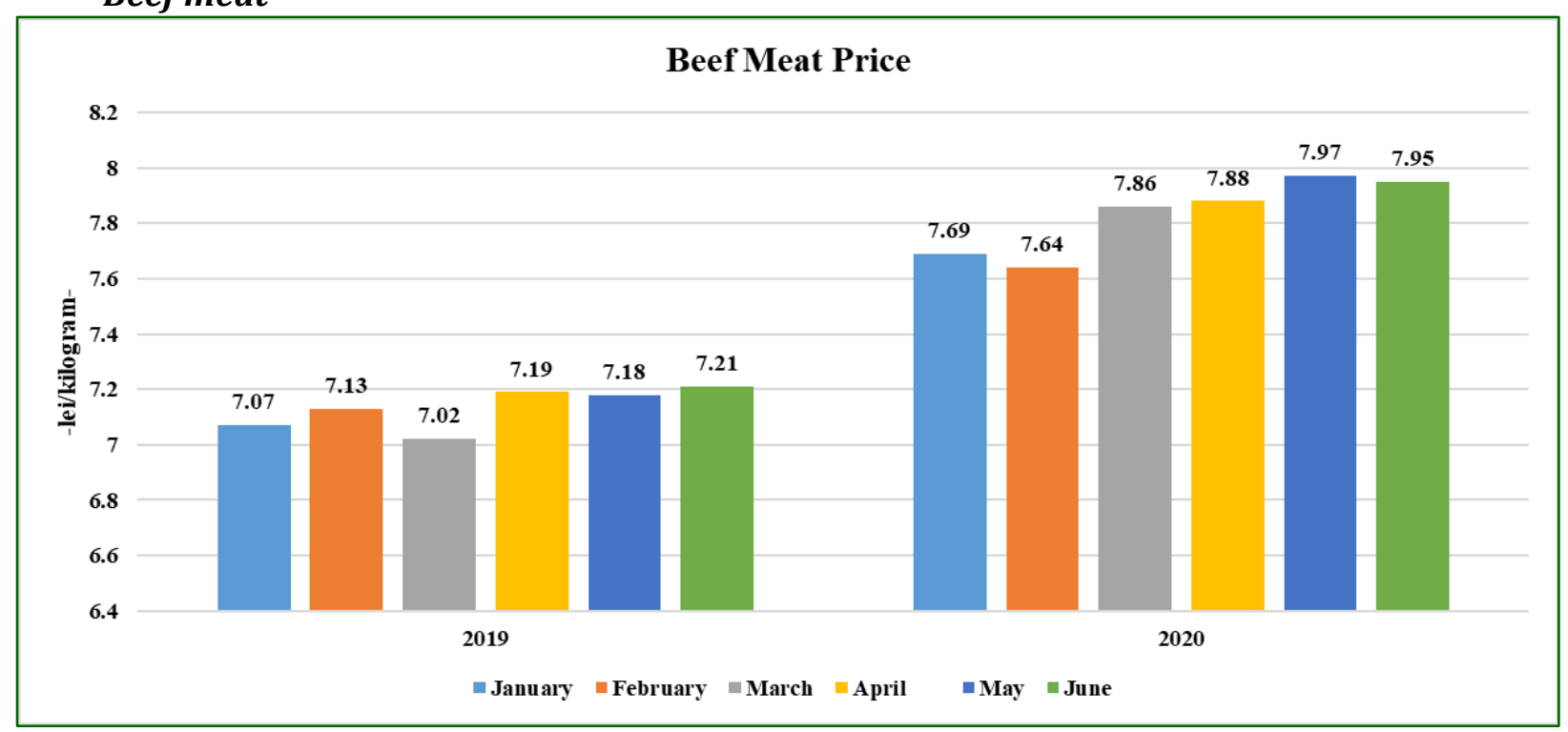

Figure 1. Dynamics of the average purchase price of beef Semester 1-2019 vs semester 1-2020

Source: Own processing based on INS data.

As can be seen from Figure 1, the price of beef in the first half of 2019 is slightly increasing, on average by $0.39 \%$ per month, with very little oscillation, the coefficient of variation being a very small $1.05 \%$, and the semester average being of 7.13 lei per kilogram.

Analyzing the prices recorded in the first half of 2020, we can see a difference in both evolution and level, respectively, during this period, the price of beef increased by $0.66 \%$ per month, slightly steeper, with a coefficient of variation of $1.74 \%$, while the average price per semester was 7.83 lei per kilogram.

In order to demonstrate, if this difference is statistically significant, the hypothesis will be tested using the $t$ test, the hypothesis being that the average value of the first 6 months of 2019 , differs from the average value of the first 6 months of 2020, respectively the difference between the means is different from zero. 
Table 1

Hypothesis testing for the price of beef

\begin{tabular}{|l|c|c|}
\hline \multicolumn{2}{|c|}{$\mathbf{2 0 2 0}$} \\
\hline Vean & 7.133333333 & 7.8317 \\
\hline Observations & 0.005626667 & 0.0186 \\
\hline Pearson Correlation & 6 & 6 \\
\hline Hypothesized Mean Difference & 0.48201872 & \\
\hline df & 0 & \\
\hline t Stat & 5 & \\
\hline P(T<=t) one-tail & -14.26623245 & \\
\hline t Critical one-tail & $1.52452 \mathrm{E}-05$ & \\
\hline $\mathrm{P}(\mathrm{T}<=\mathrm{t})$ two-tail & 2.015048373 & \\
\hline $\mathrm{t}$ Critical two-tail & $3.04903 \mathrm{E}-05$ & \\
\hline Source: Own calculations & 2.570581836 & \\
\hline
\end{tabular}

Source: Own calculations based on the data in figure 1 using Data Analysis of MS Excel.

Table 1 shows that the absolute value of the statistical parameter t State is higher than the critical value ( $t$ Critical) and the significance level $P$ is lower than the maximum accepted threshold of 0.05 , which confirms the hypothesis, respectively the difference between the averages cannot be zero, in other words there is no possibility for the averages to be the same. As previously determined, the average price in the first half of 2020 (7.83 lei $/ \mathrm{kg})$ is $9.8 \%$ higher than the average price in the first half of 2019.

\section{Sheep meat}

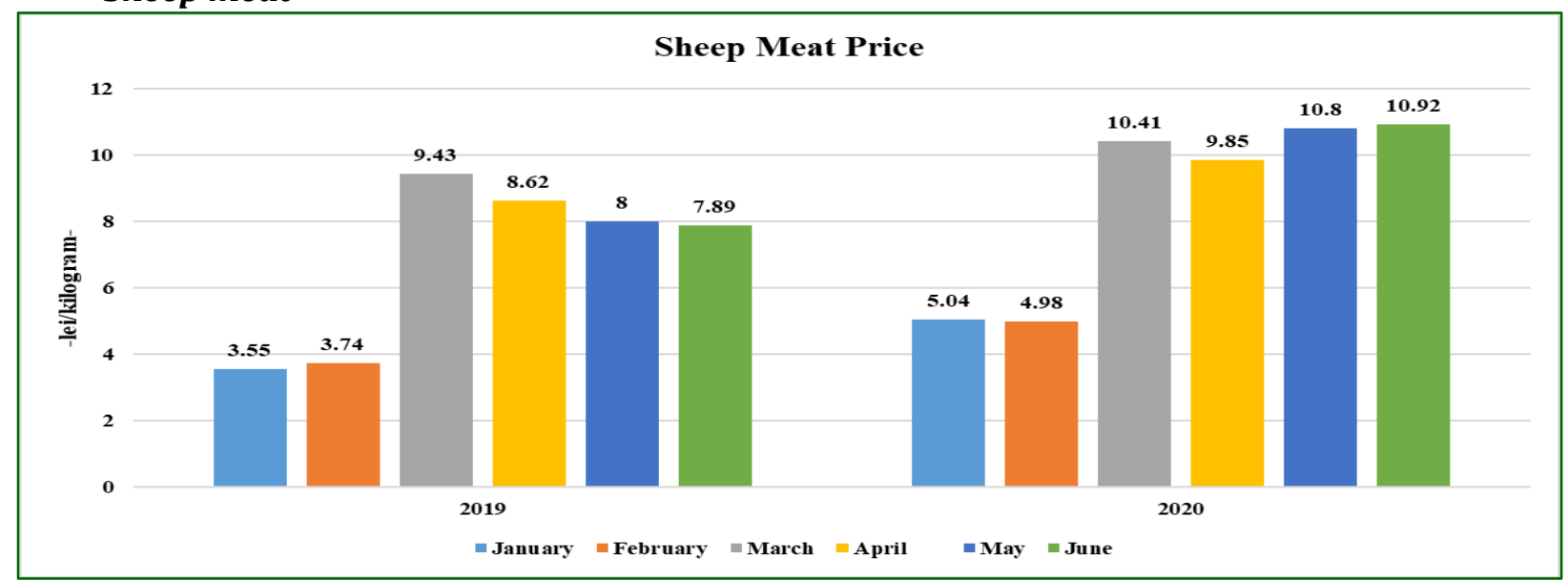

Figure 2. Dynamics of the average purchase price of sheep meat Semester 1-2019 vs semester 1-2020

Source: Own processing based on INS data.

As can be seen from Figure 2, the price of sheep meat in the first half of 2019, is increasing, on average, by $17.3 \%$ per month, with very high oscillation, the coefficient of variation being a very high $37.24 \%$, and the average for the semester being 6.87 lei per kilogram.

Analyzing the prices recorded in the first half of 2020, we can see a difference in both evolution and level, respectively, during this period, the price of sheep meat increased by $16.72 \%$ per month, slightly slower, with a coefficient of variation of $32.97 \%$, and the average price of the semester was 8.66 lei per live kilogram.

In order to demonstrate, if this difference is statistically significant, the hypothesis will be tested using the $t$ test, the hypothesis being that the average value of the first 6 months of 2019, differs from the average value of the first 6 months of 2020, respectively the difference between the means being different from zero. 
Testing the hypothesis for the price of sheep meat

\begin{tabular}{|l|c|c|}
\hline \multicolumn{2}{|c|}{$\mathbf{2 0 2 0}$} \\
\hline Mean & 6.871666667 & 8.6667 \\
\hline Obariance & 6.550536667 & 8.1625 \\
\hline Pearson Correlation & 6 & 6 \\
\hline Hypothesized Mean Difference & 0.952450588 & \\
\hline df & 0 & \\
\hline t Stat & 5 & \\
\hline P(T<=t) one-tail & -4.965876286 & \\
\hline t Critical one-tail & 0.002113365 & \\
\hline P(T<=t) two-tail & 2.015048373 & \\
\hline t Critical two-tail & 0.00422673 & \\
\hline$S$ Source: Owncalculations & 2.570581836 & \\
\hline
\end{tabular}

Source: Own calculations based on the data in figure 1 using Data Analysis of MS Excel.

It can be seen from Table 2 that the absolute value of the statistical parameter $t$ State is higher than the critical value ( $t$ Critical), and the significance level $P$ is lower than the maximum accepted threshold of 0.05 , so it may be seen that the hypothesis is confirmed, respectively the difference between the averages cannot be zero, in other words there is no possibility for the averages to be the same. As previously determined, the average price in the first half of 2020 (8.66 lei/kg) is $26.12 \%$ higher than the average price in the first half of 2019.

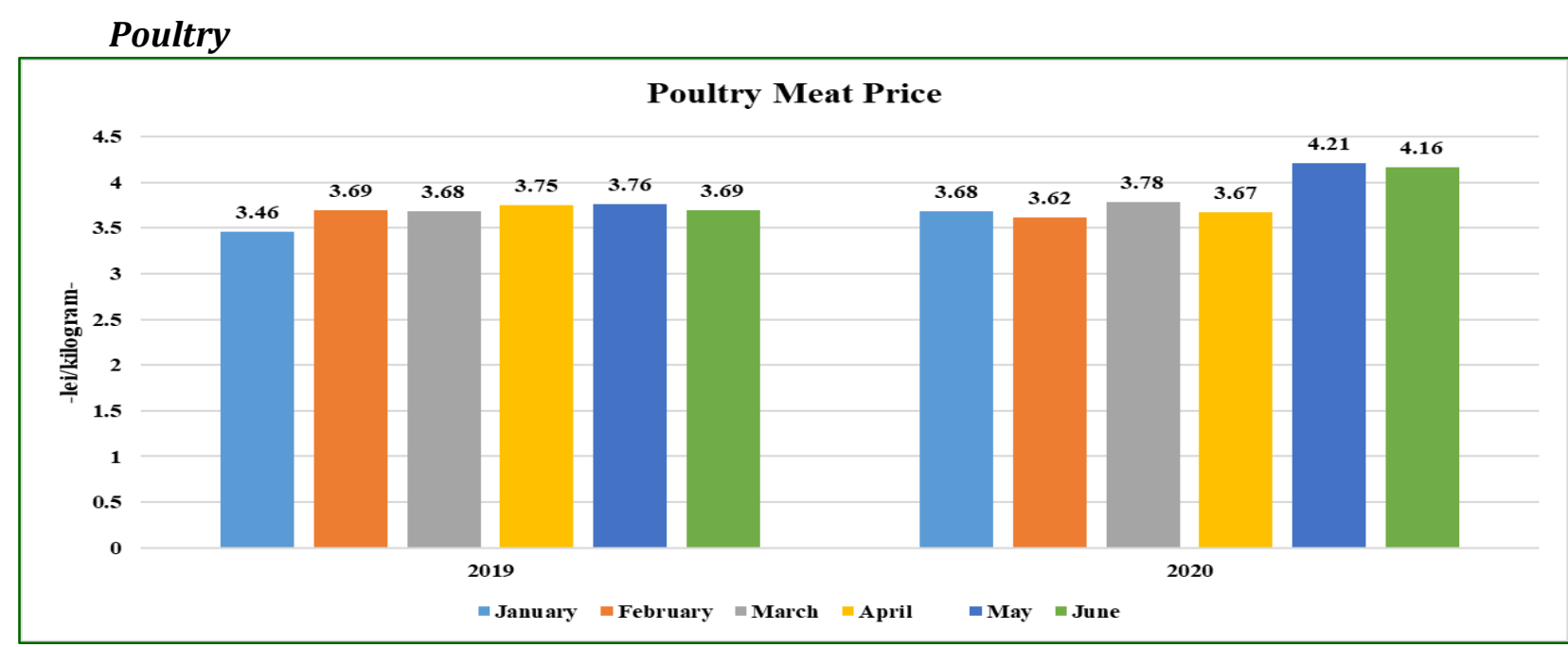

Figure 3. Dynamics of the average purchase price of poultry

Semester 1-2019 vs semester 1-2020

Source: Own processing based on INS data.

As can be seen from Figure 3, the price of poultry in the first half of 2019 is slightly increasing, on average by $1.3 \%$ per month, the coefficient of variation being low, $2.97 \%$, and the average of the semester being of 3.67 lei per kilogram. Analyzing the prices recorded in the first half of 2020, we can see a difference in both evolution and level, respectively, during this period, the price of poultry increased monthly by $2.48 \%$, a slightly more alert pace, with a coefficient of variation of $6.81 \%$, and the average price of the semester was 3.85 lei per live kilogram.

In order to demonstrate, if this difference is statistically significant, the hypothesis will be tested using the $t$ test, the hypothesis being that the average value of the first 6 months of 2019, differs from the average value of the first 6 months of 2020, respectively the difference between the means being different from zero. 
Table 3

Hypothesis testing for the price of poultry 2019

\begin{tabular}{|l|c|c|}
\hline Mean & 3.671666667 & 3.8533 \\
\hline Variance & 0.011896667 & 0.0689 \\
\hline Observations & 6 & 6 \\
\hline Pearson Correlation & 0.381055414 & \\
\hline Hypothesized Mean Difference & 0 & \\
\hline df & 5 & \\
\hline t Stat & -1.831738757 & \\
\hline P(T<=t) one-tail & 0.063242222 & \\
\hline t Critical one-tail & 2.015048373 & \\
\hline $\mathrm{P}(\mathrm{T}<=\mathrm{t})$ two-tail & 0.126484443 & \\
\hline t Critical two-tail & 2.570581836 & \\
\hline Source: Owncalculations based on the data in figure & \\
\hline
\end{tabular}

Source: Own calculations based on the data in figure 1 using Data Analysis of MS Excel.

It can be seen from Table 3 that the absolute value of the statistical parameter $t$ State is lower than the critical value ( $\mathrm{t}$ Critical) and the significance level $\mathrm{P}$ is higher than the maximum accepted threshold of 0.05 , so it cannot be estimated that the hypothesis is confirmed, respectively the difference between the means can be zero, in other words there is a possibility that the means are the same.

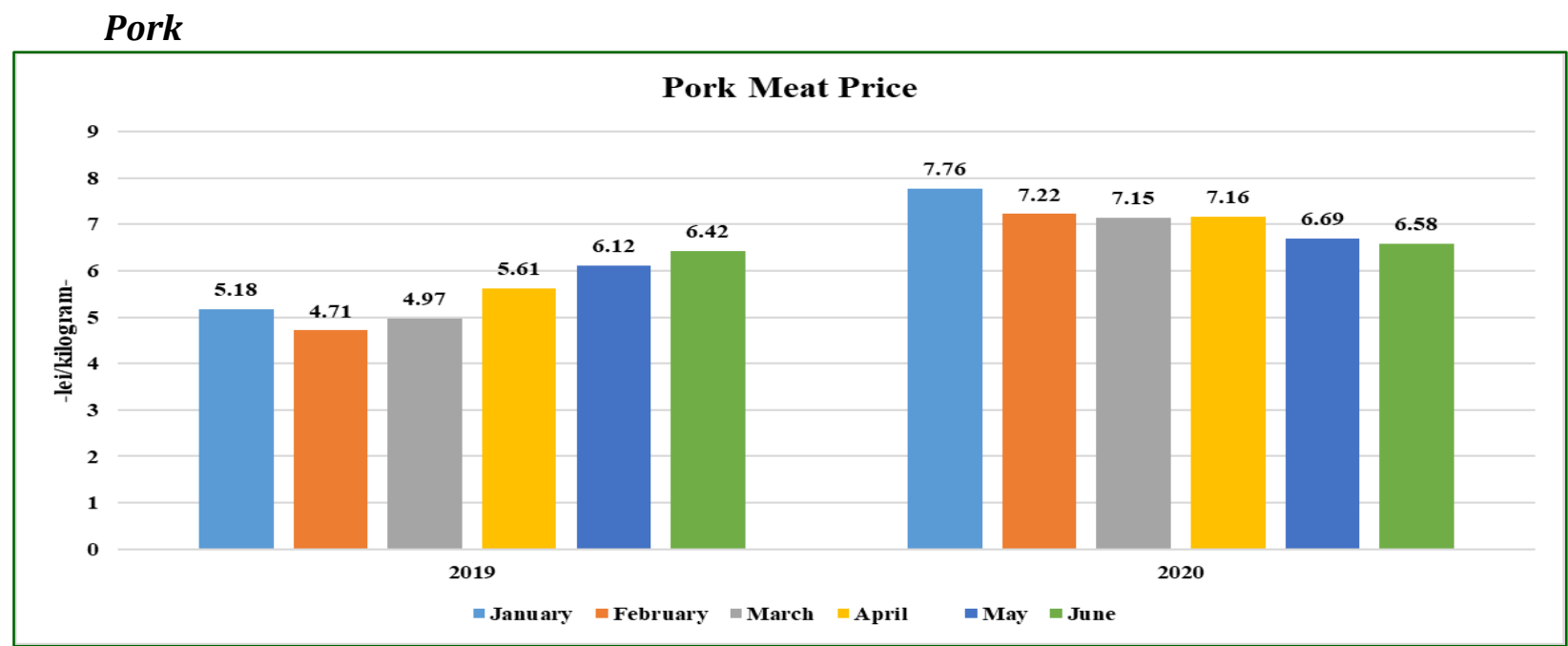

Figure 4. Dynamics of the average purchase price of pork Semester 1-2019 vs semester 1-2020

Source: Own processing based on INS data.

As can be seen from Figure 4, the price of pork in the first half of 2019 is increasing, on average, by $4.38 \%$ per month, the coefficient of variation being average, $12.2 \%$, and the average of the semester being 5.5 lei per kilogram.

Analyzing the prices recorded in the first half of 2020, we can see a difference in both evolution and level, respectively, during this period, the price of pork decreased, but starting from another level, the monthly average was $-3.24 \%$, with a $5.96 \%$ coefficient of variation of and the average price for the semester of 7.09 lei per kilogram.

In order to demonstrate, if this difference is statistically significant, the hypothesis will be tested using the $t$ test, the hypothesis being that the average value of the first 6 months of 2019 , differs from the average value of the first 6 months of 2020, respectively the difference between the means is different from zero. 
Testing the hypothesis for the price of pork

\begin{tabular}{|l|c|c|}
\hline \multicolumn{1}{|c|}{ Mean } & $\mathbf{2 0 1 9}$ & $\mathbf{2 0 2 0}$ \\
\hline Variance & 5.501666667 & 7.0933 \\
\hline Observations & 0.450056667 & 0.1789 \\
\hline Pearson Correlation & 6 & 6 \\
\hline Hypothesized Mean Difference & -0.746096835 & \\
\hline df & 0 & \\
\hline$t$ Stat & 5 & \\
\hline$P(T<=t)$ one-tail & -3.800656752 & \\
\hline$t$ Critical one-tail & 0.006310001 & \\
\hline$P(T<=t)$ two-tail & 2.015048373 & \\
\hline$t$ Critical two-tail & 0.012620002 & \\
\hline
\end{tabular}

Source: own calculations based on the data in figure 1 using Data Analysis of MS Excel

It can be seen from Table 4 that the absolute value of the statistical parameter $t$ State is higher than the critical value ( $t$ Critical), and the significance level $\mathrm{P}$ is lower than the maximum accepted threshold of 0.05 , so it can be seen that the hypothesis it is confirmed, respectively the difference between the averages cannot be zero, in other words there is no possibility for the averages to be the same. As previously determined, the average price in the first half of 2020 (7.09 lei $/ \mathrm{kg}$ ) is 28.9\% higher than the average price in the first half of 2019.

\section{Cow milk}

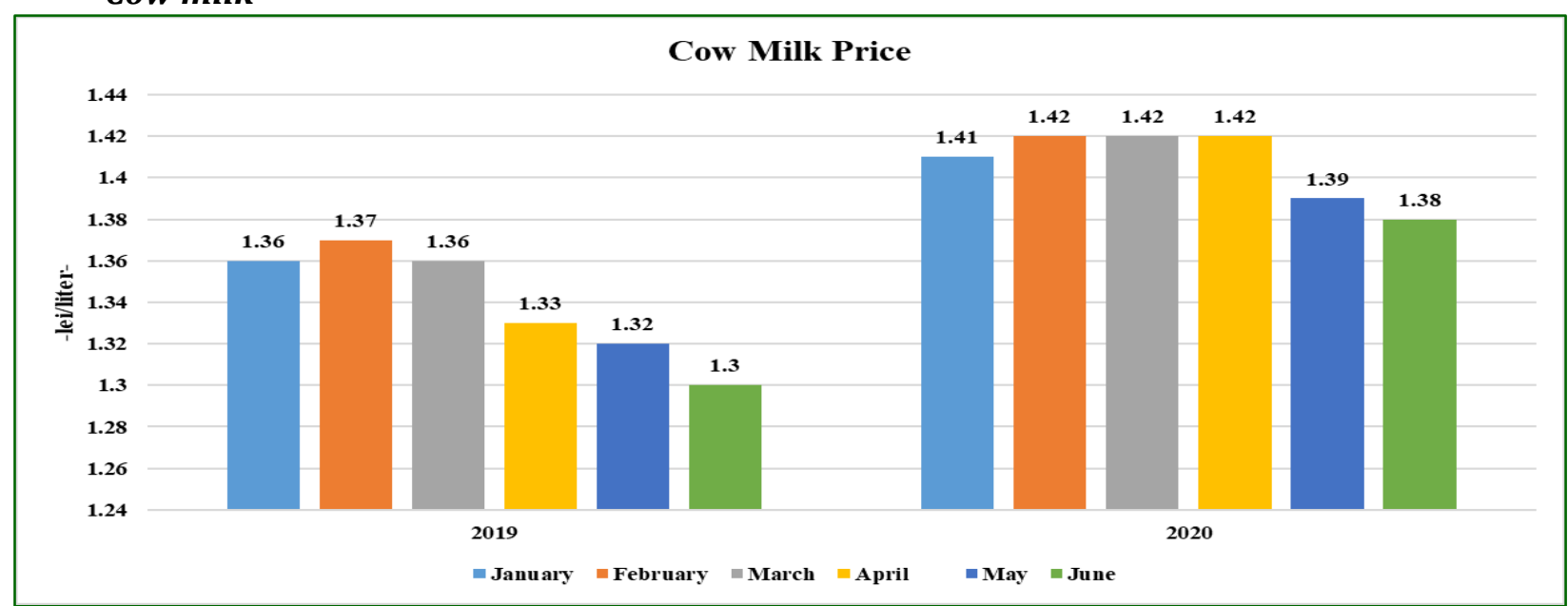

Figure 5. Dynamics of the average purchase price of cow's milk Semester 1-2019 vs semester 1-2020

Source: Own processing based on INS data.

As can be seen from Figure 5, the price of cow's milk in the first half of 2019, shows a decreasing trend, on average, by $0.9 \%$ per month, the coefficient of variation being a small $2.05 \%$, and the average of the semester being 1.34 lei per liter. Analyzing the prices recorded in the first half of 2020, a similar evolution can be observed, but at a different level, respectively, during this period, the price of cow's milk decreased, but starting from another level, on average the monthly rate was $-0.43 \%$, with a $1.24 \%$ coefficient of variation the average price for the semester being 1.4 lei per liter.

In order to demonstrate, if this difference is statistically significant, the hypothesis will be tested using the $t$ test, the hypothesis being that the average value of the first 6 months of 2019, differs from the average value of the first 6 months of 2020, respectively the difference between the means is different from zero. 
Table 5

Testing the hypothesis for the price of cow's milk

\begin{tabular}{|l|c|c|}
\hline \multicolumn{2}{|c|}{$\mathbf{2 0 2 0}$} \\
\hline Mean & $\mathbf{2 0 1 9}$ & 1.4067 \\
\hline Obariance & 1.34 & 0.0003 \\
\hline Pearson Correlation & 0.00076 & 6 \\
\hline Hypothesized Mean Difference & 6 & \\
\hline df & 0.828552265 & \\
\hline$t$ Stat & 0 & \\
\hline P(T<=t) one-tail & -10 & \\
\hline t Critical one-tail & $8.54738 \mathrm{E}-05$ & \\
\hline P(T<=t) two-tail & 2.015048373 & \\
\hline t Critical two-tail & 0.000170948 & \\
\hline$S$ Source: Owncalculations & 2.570581836 & \\
\hline
\end{tabular}

Source: Own calculations based on the data in figure 1 using Data Analysis of MS Excel.

It can be seen from Table 5 that the absolute value of the statistical parameter $t$ State is higher than the critical value ( $\mathrm{C}$ Critical) and the significance level $\mathrm{P}$ is lower than the maximum accepted threshold of 0.05 , so it can be seen that the hypothesis is confirmed, respectively that the difference between the averages cannot be zero, in other words there is no possibility for the averages to be the same. As previously determined, the average price in the first half of 2020 (1.406 lei/l) is 4.97\% higher than the average price in the first half of 2019.

\section{Chicken eggs}

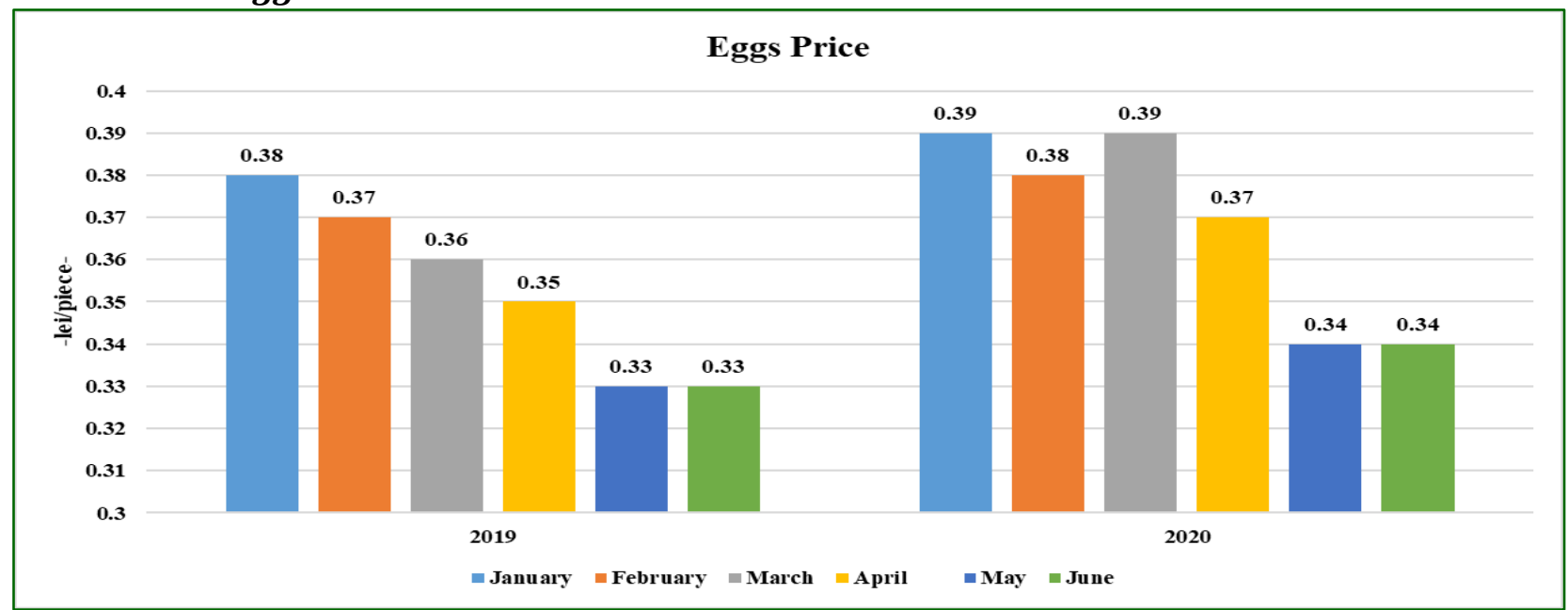

Figure 6. Dynamics of the average purchase price of chicken eggs

Semester 1-2019 vs semester 1-2020

Source: Own processing based on INS data.

As can be seen from Figure 6, the price of chicken eggs in the first half of 2019 shows a decreasing trend, on average, by $2.78 \%$ per month, the coefficient of variation being small, $5.85 \%$, and the average semester price being of 0.353 lei per piece. Analyzing the prices recorded in the first half of 2020 , a similar evolution can be observed, but at a different level, respectively, during this period, the price of chicken eggs decreased, but starting from another level, on average the monthly rate was $-2.7 \%$, with a coefficient of variation of $6.29 \%$, and the average price of the semester was 0.388 lei per piece.

In order to demonstrate, if this difference is statistically significant, the hypothesis will be tested using the $t$ test, the hypothesis being that the average value of the first 6 months of 2019, differs from the average value of the first 6 months of 2020, respectively the difference between the means being different from zero. 
Table 6

Hypothesis testing for the price of chicken eggs

\begin{tabular}{|c|c|c|}
\hline & 2019 & 2020 \\
\hline Mean & 0.353333333 & 0.3683 \\
\hline Variance & 0.000426667 & 0.0005 \\
\hline Observations & 6 & 6 \\
\hline Pearson Correlation & 0.933441006 & \\
\hline Hypothesized Mean Difference & 0 & \\
\hline $\mathrm{df}$ & 5 & \\
\hline t Stat & -4.391550328 & \\
\hline $\mathrm{P}(\mathrm{T}<=\mathrm{t})$ one-tail & 0.003538799 & \\
\hline t Critical one-tail & 2.015048373 & \\
\hline $\mathrm{P}(\mathrm{T}<=\mathrm{t})$ two-tail & 0.007077598 & \\
\hline t Critical two-tail & 2.570581836 & \\
\hline
\end{tabular}

Source: Own calculations based on the data in figure 1 using Data Analysis of MS Excel.

It can be seen from Table 6 that the absolute value of the statistical parameter $t$ State is higher than the critical value ( $t$ Critical), and the significance level $\mathrm{P}$ is lower than the maximum accepted threshold of 0.05 , so it can be seen that the hypothesis is confirmed, respectively the difference between the averages cannot be zero, in other words there is no possibility for the averages to be the same. As previously determined, the average price in the first half of 2020 (0.388 lei/piece) is 4.25\% higher than the average price in the first half of 2019.

Following these analyzes on the price difference between the first half of 2020 and the first half of 2019, on the main agricultural products of animal origin, it can be stated that for 5 of the 6 products analyzed the prices increased significantly in 2020, compared to the same period of last year. Among the reasons it can be appreciated that the drought at the beginning of the agricultural year 2019-2020, continued with the one at the beginning of the calendar year 2020, significantly affected the crops, implicitly the animal feed. On the other hand, we consider that the Covid-19 pandemic indirectly affected the price of these products, which are somewhat dependent on imports, and the reduction of trade led to higher prices.

In this regard, two analyzes were performed on the two reasons stated above, thus, correlation coefficients were determined between the prices of agricultural products and the level of precipitation in the months under study.

Table 7 Correlation of precipitation with the price of the main agricultural products of animal origin

\begin{tabular}{|c|c|c|c|c|c|c|c|}
\hline & $\begin{array}{l}\text { Average } \\
\text { rainfall }\end{array}$ & $\begin{array}{l}\text { Poultry } \\
\text { price }\end{array}$ & $\begin{array}{l}\text { Beef } \\
\text { meat } \\
\text { price }\end{array}$ & $\begin{array}{l}\text { Sheep } \\
\text { meat } \\
\text { price }\end{array}$ & $\begin{array}{l}\text { Pork } \\
\text { meat } \\
\text { price }\end{array}$ & $\begin{array}{l}\text { Cow } \\
\text { milk } \\
\text { price }\end{array}$ & $\begin{array}{l}\text { Eggs } \\
\text { price }\end{array}$ \\
\hline Average rainfall & 1 & & & & & & \\
\hline Poultry price & 0.49056 & 1 & & & & & \\
\hline Beef price & 0.05613 & 0.61255 & 1 & & & & \\
\hline Sheep meat price & 0.34161 & 0.69479 & 0.50596 & 1 & & & \\
\hline Pork price & -0.02008 & 0.22955 & 0.79809 & 0.26272 & 1 & & \\
\hline Cow milk price & -0.45690 & 0.08564 & 0.72107 & 0.04102 & 0.56559 & 1 & \\
\hline Eggs price & -0.73915 & -0.51408 & 0.14983 & -0.45112 & 0.21952 & 0.72759 & 1 \\
\hline
\end{tabular}

Source: Own calculations based on data https://www.catd.ro/ and INS using Data Analysis of MS Excel.

In table 7 it can be seen that there are only 3 links of medium and close intensity, between precipitation and the price of agricultural products (poultry, milk and eggs). There is a correlation coefficient of 0.49 between precipitation and the price of poultry, which suggests that there is a link of medium and positive intensity, contrary to the purpose of this analysis. For the other two quite strong relations, there is a correlation coefficient of -0.456 between the level of precipitation and the price of 
milk and of -0.739 between precipitation and the price of eggs. These links of medium and high intensity, inversely proportional, show that when the level of precipitation decreases the price level for these two products increases, which is very possible to have happened this agricultural year as well.

In order to understand the impact that the COVID-19 pandemic had on prices, but also vice versa, the consumption of milk and eggs in the months analyzed and similarly correlated with the Pearson coefficient was analyzed.

Table 8

Correlation of average monthly consumption with the price of the main agricultural products of animal origin

\begin{tabular}{|l|c|c|}
\hline Cow Milk & Monthly consumption & Price \\
\hline Monthly consumption & 1 & 1 \\
\hline Price & -0.88902 & Price \\
\hline Eggs & Monthly consumption & \\
\hline Monthly consumption & 1 & 1 \\
\hline Price & -0.80535 & \\
\hline
\end{tabular}

Source: Own calculations based on INS data using Data Analysis of MS Excel.

As can be seen in Table 8, which determines the Pearson correlation coefficients between the price of milk and eggs and their average monthly consumption, in both cases, the coefficient has a close intensity relationship, but an inverse relationship. This can be contradicted by economic theory, but in this case, given that the value of the coefficients is over 0.8 , representing a close relationship, it can be seen that when the price rose due to drought, and the difficulty of trade due to the pandemic, corroborated by the fact that the income level of the population decreased during this period, the consumption of these products of animal origin decreased, given the opposite trend to increase consumption of the main staple foods; the latter have replaced much of the animal protein, given the rising price and declining income of the population.

\section{CONCLUSIONS}

The aim of this paper was to determine the impact that the Covid-19 pandemic and the drought of this agricultural year may have on the prices of the main agricultural products of animal origin.

In this sense, the price levels were compared in the first half of 2019 and 2020, in order to determine the differences between them. Prices were studied for the following products: the four main species of meat (cattle, sheep, poultry and pigs), cow's milk and eggs. Following the analysis and testing of the hypothesis, using the t test, according to which the prices in the first half of 2020 are higher than in the first half of 2019, it was true for five of the six products analyzed, with the exception of poultry.

In order to determine whether the drought at the beginning of the agricultural year 2019-2020 and at the beginning of the calendar year 2020 affected the prices of the products under analysis, the level of precipitation in both periods and correlated with the Pearson correlation coefficient was taken into account. It was found that there is an indirect influence between the level of precipitation and the price of milk and eggs, in the sense that when the level of precipitation decreases, prices increase, this fact being easily explained given the plant production which is directly conditioned by meteorological factors and the share feed in the cost of obtaining milk and eggs is very high reaching almost $50 \%$.

Analyzing the influence of the Covid-19 pandemic on the level of prices, the level of average monthly consumption was taken into account, this being recorded by statistics only for milk and eggs. Thus, performing a similar analysis, using the Pearson correlation coefficient, it was found that between the price level and the demand level there is a very close relationship, however, an inversely proportional one. Thus, it can be seen that although demand has decreased, the price level has increased. This strange phenomenon from the point of view of economic theory, is easy to explain given the situation we are going through. With the onset of the state of emergency, demand increased significantly, but this was only for staple and staple foods, coupled with declining household incomes and rising prices for animal products, there was a significant decline in consumption. The impact of the pandemic on the price of animal products can be identified in trade relations, which are altered by this unexpected phenomenon, so a reduction in supply on the market of these products has been noted by an increase in their price. 
It can be concluded that both the drought and the COVID-19 pandemic indirectly influenced the prices of the main agricultural products of plant origin, the drought by decreasing plant production and thus increasing the cost of feed, and the pandemic by restricting trade, leading to declining market supply. and rising prices, and this rise in prices coupled with declining revenues has led to a decline in the consumption of these products.

A1. Average Precipitation level

\begin{tabular}{|l|c|c|}
\hline Precipitation level & $\mathbf{2 0 1 9}$ & $\mathbf{2 0 2 0}$ \\
\hline January & $\mathbf{7 8 . 7 5}$ & 9.725 \\
\hline February & 11.475 & 52.075 \\
\hline March & 36.6 & 37.6 \\
\hline April & 48.95 & 25.15 \\
\hline May & 152.7 & 93.025 \\
\hline June & 87.15 & 148.125 \\
\hline
\end{tabular}

Source: https://www.catd.ro/

A2. Dynamics of average monthly consumption

\begin{tabular}{|l|c|c|c|}
\hline & $\mathbf{Q 1}-\mathbf{1 9}$ & $\mathbf{Q 2}-\mathbf{1 9}$ & $\mathbf{Q 1}$ - 20 \\
\hline Milk Demand & 5.497 & 5.513 & 4.053 \\
\hline Eggs Demand & 12.801 & 14.666 & 13.368 \\
\hline
\end{tabular}

Source: NIS.

\section{REFERENCES}

1. ANH, D.L.T., GAN, C. The impact of the COVID-19 lockdown on stock market performance: evidence from Vietnam. In: Journal of Economic Studies. 2020, vol. ahead-of-print, no. ahead-of-print. ISSN 0144-3585 [cited 21 october 2020]. Available: https://doi.org/10.1108/JES-06-2020-0312

2. BUTU, A. et al. The Impact of COVID-19 Crisis upon the Consumer Buying Behavior of Fresh Vegetables Directly from Local Producers. Case Study: The Quarantined Area of Suceava County, Romania. In: International Journal of Environmental Research and Public Health. 2020, vol. 17, no. 15, p. 5485. ISSN 1660-4601 [cited 12 october 2020]. Available: https://doi.org/10.3390/ijerph17155485

3. CAO, L. et al. Impact of COVID-19 on China's agricultural trade. In: China Agricultural Economic Review. 2020, vol. ahead-of-print, no. ahead-of-print. ISSN 1756-137X [cited 19 october 2020]. Available: https://doi.org/10.1108/CAER-05-2020-0079

4. FAN, S. et al. How to prevent a global food and nutrition security crisis under COVID-19? In: China Agricultural Economic Review. 2020, vol. 12, no. 3, pp. 471-480. ISSN 1756-137X [cited 27 october 2020]. Available: https://doi.org/10.1108/CAER-04-2020-0065

5. ZHANG, S. et al. The impact of epidemics on agricultural production and forecast of COVID-19. In: China Agricultural Economic Review. 2020, vol. 12, no. 3, pp. 409-425. ISSN 1756-137X [cited 22 october 2020]. Available: https://doi.org/10.1108/CAER-04-2020-0055

6. ZHANG, Y. et al. Impact of COVID-19 on China's macroeconomy and agri-food system - an economy-wide multiplier model analysis. In: China Agricultural Economic Review, 2020 vol. 12, no. 3, pp. 387-407. ISSN 1756-137X [cited 16 october 2020]. Available: https://doi.org/10.1108/CAER-04-2020-0063

7. COMPANIA DE APĂ TÂRGOVIȘTE DÂMBOVIȚA. The precipitation level [cited 03 october 2020]. Available: https://www.catd.ro/

8. INSTITUTUL NAȚIONAL DE STATISTICĂ [cited 09 october 2020]. Available: www.insse.ro

9. Ordonanța de Urgență (Emergency Decree): nr. 148 din 27 august 2020. In: Monitorul Oficial al României. 2020, nr. 806 [cited 24 october 2020]. Available: http://legislatie.just.ro/Public/DetaliiDocument/229703

\section{ARTICLE HISTORY}

Received 26 June 2020

Accepted 12 December 2020 